\title{
ПСИХОЛОГІЧНИЙ АНАЛІЗ ЗМІСТУ ВНУТРІШНЬООСОБИСТІСНИХ СТИМУЛІВ ПРОФЕСІЙНОЇ САМОРЕАЛІЗАЦІЇ В ЗАРУБІЖНІЙ ТА ВІТЧИЗНЯНІЙ НАУКОВИХ ПАРАДИГМАХ
}

\section{Мазай Л. Ю., Павлушенко О. А.}

\section{ВСТУП}

Швидкий розвиток науково-технічного прогресу та глобалізаційних процесів зумовлює зміни умов трудової діяльності людини та створює високий рівень конкуренції на ринку праці, що робить, у свою чергу, украй актуальною проблему професійної самореалізації. Сьогодні можемо спостерігати кардинальну трансформацію наукових, технічних і культурних сфер життєдіяльності, які під впливом функціонування масової культури транслюють як нові цінності та норми в саморозвитку та самоактуалізації, так і пропонують нові форми самовираження для сучасної молоді. У цьому контексті постає важливою проблема визначення психологічних особливостей внутрішньоособистісних стимулів професійної самореалізації, а саме тих глибинних мотиваційних чинників, які могли б стати сприятливою основою для формування професійної ідентифікації та самосвідомості, інтеріоризації необхідних фахових цінностей, норм i правил, ефективної реалізації особистісного потенціалу для успішного фахового становлення та розвитку.

Останніми роками у фокус активного наукового аналізу таких дослідників, як А. Деркач, Е. Зеєр, Є. Клімов і В. Марищук, потрапляють різноманітні особистісні чинники професійної готовності, які можуть слугувати детермінантами успішного професійного розвитку. У межах останньої проблематики варто згадати дисертаційні дослідження індивідуального ресурсу як основи становлення професіоналізму С. Дружилова. Також різноманітні аспекти професійного розвитку як системного та комплексного процесу досліджували В. Андрущенко, О. Анісімов, О. Болотова, В. Кремень, Н. Кузьміна, С. Максименко, А. Маркова, Л. Мітіна, Л. ОрбанЛембрик, Н. Пов'якель, Ф. Парсонс, Г. Мюнстенберг, Т. Боген, У. Мозей, Е. Бордін, Е. Роу, Дж. Холланд, Х. Томс, Г. Рис, Д. Лідеман, Д. Сьюпер, Дж. Левінджер. Проблематика особистісної та професійної самореалізації стала предметом наукових праць К. АбульхановоїСлавської, Б. Ананьєва, Л. Анциферової, В. Клочкового, 
Е. Галажинського, I. Сгоричева, П. Коростильова, Д. Леонтьєва, Д. Фельдштейн, С. Кудінова, І. Костакова й ін. Однак у жодному з досі реалізованих досліджень не підлягали теоретичному й емпіричному аналізу психологічні особливості внутрішньоособистісних стимулів професійної самореалізації, що підтверджує актуальність порушеної нами проблематики.

Метою розвідки $є$ репрезентація результатів теоретичного осмислення змісту поняття внутрішньоособистісних стимулів як одного 3 основоположних чинників мотиваційного забезпечення професійної самореалізації. Такий аналіз пропонованої психологічної властивості допоможе детальніше окреслити перспективи наукового дослідження в цій проблематиці.

\section{1. Визначення поняття внутрішньоособистісних стимулів професійної самореалізації в парадигмі психоаналітичного} та гуманістичного наукових дискурсів

Поняття внутрішньоособистісних стимулів за своїм лексичним і змістовим параметрами $є$ широким та багатоаспектним, що потребує уточнення та конкретизації. Важливим у визначенні суті, змісту та складових частин цієї комплексної властивості є розуміння первинної ланки, яка є основою для стимуляції не лише діяльності, самореалізації, зокрема професійної, а й існування людини загалом. Гіпотетично в ролі такої ми могли б розглядати потреби індивіда, згідно 3 якими формуються мотиви, інтереси, цінності та цілі особистості. Однак, на нашу думку, для повного осмислення суті поняття варто звернутись до глибокого аналізу та порівняння теорій ядра особистості як закордонних, так і вітчизняних науковців.

У психологічній енциклопедії стимул визначається як спонукальна причина поведінки, яка зумовлює певну реакцію індивіда й відноситься до неї як причина до наслідку; це спонукання, результат якого опосередковується психікою людини: ii світоглядом, інтересами, настроями тощо ${ }^{1}$. Однак для формування цих параметрів психіки необхідні певні рушійні сили, що визначають специфіку та вектори розвитку людини як біологічної істоти, соціалізованої особистості, формують іiі спрямованості на ті чи ті об'єкти соціокультурного життя, визначають окреслення цінностей, до системи яких може належати або не належати самореалізація, зокрема професійна.

Серед наукових теорій та концепцій, у фокусі уваги яких перебуває осмислення механізмів контролю та специфікації поведінки індивіда, одну із провідних ролей відіграють так звані конфліктні моделі, а саме

${ }^{1}$ Степанов О. Психологічна енциклопедія. Київ : Академвидав, 2006. 424 с. 
в рамках психодинамічного напряму. Одним із визначальних стимулів поведінки 3. Фрейд називає прагнення до задоволення та пошук щастя, яке людина може знаходити в духовній та культурній сфері, приналежності до соціуму, виконанні улюбленої та суспільно корисної справи. Ось що пише науковець про значення трудової діяльності у процесі забезпечення задоволення: «Жодна інша техніка керівництва життям не пов'язує так міцно з реальністю, як захоплення роботою. Вона надійно включає індивіда принаймні в одну сферу реальності - у соціум. Можливість переміщення значної частини лібідонозних компонентів - нарцистичних, агресивних і власне еротичних - у трудову сферу та пов'язані 3 нею людські стосунки надають цій діяльності цінності, яка не менша за необхідність підтримки та виправдання свого існування в суспільстві. Коли професійна діяльність вільно обрана, вона приносить особливе задоволення: за допомогою сублімації стають корисними схильності, домінантні або конституціонально посилені прагнення» ${ }^{2}$. На основі аналізу таких рефлексій можемо зробити висновок, що фахова діяльність $є$ процесом сублімації, ціллю якої стає професійна самореалізація як спосіб підтвердження індивідом свого існування в соціумі, а також відчуття однієї із частин реальності буття. Тут прагнення заявити про себе i набути приналежність до суспільства слугує внутрішньоособистісним стимулом професійної самореалізації, що у своїх первісних інстинктивних прагненнях спрямовує людину до духовного та соціокультурного задоволення.

На противагу теоріям конфлікту, осмислення проблематики ядра особистості, що забезпечує тенденцію актуалізації, детально представлене в наукових працях психологів-гуманістів. Як і у випадку 3 оглядом теоретичних досліджень із питань самоактуалізації й самореалізації, пошуки основ внутрішньоособистісних стимулів варто розпочати 3 поглядів К. Роджерса. 3 визначення, що дає науковець поняттю тенденції самоактуалізації як прагненню вести себе і розвиватись (отримувати унікальний досвід) згідно з тим, як людина свідомо себе сприймає, стає очевидною роль «самості» (або «Я-концепції») у забезпеченні цього процесу, що є образом себе. У розумінні К. Роджерса, «Я-концепція»- це безпосередньо людський прояв, щоби зрозуміти, як вона виникає, треба розглянути два додаткові відгалуження тенденції актуалізації. Це потреба в позитивній увазі й потреба в позитивній увазі до себе ${ }^{3}$. Обидві ці потреби вважаються вторинними або набутими, зазвичай вони розвиваються в

${ }^{2}$ Фрейд 3. Недовольство культурой. Санкт-Петербург : Фолио, 2013. 222 с.

${ }^{3}$ Rogers C. The necessary and sufficient conditions of therapeutic personality change. Psychotherapy: Theory, Research, Practice, Training. 2007. № 44 (3). 256 p. 
ранньому дитинстві, $\epsilon$ особливими проявами загальної тенденції актуалізації. Потреба в позитивній увазі належить до задоволення, яке відчуває суб'єкт, отримуючи схвалення 3 боку інших людей, i до фрустрації, яка виникає в разі несхвалення. Потреба в позитивній увазі до себе - більш інтеріоризований варіант першої потреби. Інакше кажучи, під потребою в позитивній увазі до себе розуміється отримання індивідом задоволення в разі самосхвалення й незадоволення за несхвалення самого себе. Маючи потребу в позитивній увазі, людина стає чутливою до оцінки iї з боку значущих осіб, такі сторонні ставлення можуть впливати на образ себе. У процесі отримання схвалення й несхвалення від авторитетних інших розвивається свідоме відчуття того, що являє собою індивід, так звана самість, або «Я-концепція». Також розвивається потреба в позитивній увазі до себе, яка забезпечує те, що тенденція самоактуалізації набуває форми переваги поведінки й розвитку, відповідних «Я-концепції». Навряд чи суб’єкт буде наполегливо діяти всупереч своїй «Я-концепції», оскільки це фруструватиме його потребу в позитивній увазі до себе 4

Зі здійсненого аналізу теорії К. Роджерса можемо припустити, що внутрішньоособистісним стимулом професійної самореалізації є образ себе, як загалом, так і в конкретній фаховій діяльності, а також потреба соціального схвалення. Це твердження підтверджує стереотипність поглядів соціуму: людина, яка активно зайнята трудовою діяльністю, отримує більше позитивних оцінок, ніж та, яка є безробітною. Разом із позитивною увагою суспільства, що репрезентується в соціальному статусі, авторитеті, повазі, індивід отримує приналежність до певної фахової спільноти, а цим доповнює свій образ професійною самоідентифікацією.

Більш деталізоване виокремлення параметрів ядра особистості, які стимулюють та забезпечують процеси самореалізації та самоактуалізації, пропонує Г. Олпорт у своїй теорії опортуністичного (біологічного) та пропріативного (психологічного, свідомого) життя. Останнє науковець визначає як вищу форму розвитку людини, яка характеризується осмисленістю й актуалізацією самості. Саме ж поняття самості Г. Олпорт визначає феноменологічно, стверджуючи, що у зміст цієї властивості входять усі об’єкти дійсності, які $\epsilon$ важливими, цінними для суб'єкта та на які спрямовані його свідомість і творча діяльність. Функціями пропріуму психолог називає відчуття індивідом свого тіла, самоідентичність, самоповагу, розширення самості, раціональне керівництво самим собою, образ себе та пропріативне прагнення - спрямування на усвідомлене, осмислене,

4 Мадди С. Теории личности: сравнительный анализ. Перев. И. Авидон, А. Батустин, П. Румянцева. Санкт-Петербург : Речь, 2002. 539 с. 
раціональне життя, що підконтрольне не лише біологічним потребам, а має соціокультурну та духовну наповненість. Розглянемо кожну функцію детальніше.

Так, першою елементарною пропріативною функцією $є$ відчуття свого тіла, яке зазвичай перебуває поза межами фокуса нашої уваги, однак тілесне самосприйняття в багатьох аспектах впливає на формування образу себе та самоставлення. Відчуття свого тіла підтримуються за допомогою кінестетичних, пропріоцептивних i тактильних сигналів та, за Г. Олпортом, бере участь в ухваленні життєво необхідних рішень.

Самоідентичність являє собою сукупність ідей, які індивід використовує для опису й визначення самого себе 5 . Таких ідентифікацій у структурі самості особистості може бути кілька, сюди входить і професійна самоідентифікація.

Самоповага $є$ третьою пропріативною функцією, яка тісно пов'язана 3 попередньо описаною та визначає основу для відчуття людиною власної цінності. Цією основою будуть уявлення про себе, багато в чому схожі на уявлення, що становлять самоідентичність, з додаванням того, що самоповага безпосередньо задає життєві орієнтири. Якщо в суб'єкта є певна самоідентичність, він буде намагатися діяти згідно 3 нею. Але дії, що суперечать ідентичності, не обов'язково будуть джерелом дискомфорту, однак уявлення про себе, пов'язані із власною цінністю, на думку Г. Олпорта, зменшують ступінь свободи поведінки особистості.

Виокремивши серед пропріативних функцій розширення самості, Г. Олпорт визнає важливість речей, людей і подій, які насправді відрізняються від нас, але посідають важливе місце в нашому житті. Ми ніби розширюємо себе або принаймні наше визначення себе так, щоби включити інші елементи навколишнього середовища. Так, для когось дорогий автомобіль, дружина, донька або колекція марок можуть бути важливими частинами його самості. Це не просто означає, що ці речі важливі в якомусь звичайному сенсі. Вони $є$ частиною самості особистості, якщо вона вважає ці речі невіддільними від себе, якщо вони підкоряються тим самим законам, що й сама людина, і їхня доля та її доля - це те саме ${ }^{6}$.

На думку Г. Олпорта, пропріативні функції, або характеристики ядра особистості, не діють незалежно одна від одної. Радше вони взаємодіють і перебувають у взаємозалежності, породжуючи життя, яке має тенденцію ядра особистості, тобто пропріативне існування. Як можна зрозуміти 3

5 Там само.

${ }^{6}$ Там само. 
характеристик ядра, таке пропріативне існування інтегрує в собі здатність старанно працювати та досягати бажаних цілей, які водночас визначаються сукупністю цінностей і принципів, а також менш абстрактним, хоча й узагальненим, відчуттям того, ким і яким є індивід, водночас усе це підконтрольне раціональному мисленню ${ }^{7}$.

3 теорії властивостей ядра особистості Г. Олпорта, що забезпечують процес самоактуалізації, можемо зробити висновок, що основною внутрішньою стимуляцією людини до дії, зокрема творчої та професійної діяльності, є тенденція до реалізації психологічної та духовної складових частин життя через механізм функціонування відчуття власного тіла, самоідентифікації, самоповаги, розширення самості. До параметрів відчуття власного тіла, окрім визначених автором концепції, можемо додати володіння суб'єктом знаннями щодо своїх потенційних фізичних можливостей i енергетичних ресурсів організму, на основі чого він робить висновок про свою придатність до виконання тієї чи тієї діяльності й вибору певної поведінки. Самоідентифікація, як було попередньо зазначено, інтегрує в собі всі значущі уявлення індивіда про себе та слугує образом, 3 яким гіпотетично здійснюється порівняння інших образів, зокрема й професійних. Цей параметр самості також може містити провідні цінності та принципи особистості, згідно 3 якими визначається важливість фахового розвитку та професійної самореалізації. Важливу роль у забезпеченні успішності професійного шляху особистості відіграє самоповага, яка грунтується на самооцінці. Модальність відчуття власної цінності визначає амбіції фахівця, його рівень домагань та претензії на якість кар'єрного й професійного росту, а також може стимулювати його прагнення досягати більшого, ніж він має в той чи інший проміжок часу. Функція розширення самості гіпотетично стимулює суб'єкта до постійного перегляду власної картини світу та включення до неї нових об’єктів навколишнього середовища. У ситуації рефлексії своїх потенційних фахових здібностей та можливостей імовірно відбувається таке розширення «Яконцепції», за якого здійснюється привласнення професійних властивостей, атрибутів і умов праці, які згодом стають важливими для суб'єкта діяльності, без яких він не уявляє свого життя. Однак останнє, на нашу думку, радше можна вважати ресурсом, що забезпечує формування професійної ідентифікації та досягнення професійної самореалізації як результату фахової діяльності, ніж внутрішньоособистісним стимулом цього процесу. Натомість

7 Мадди С. Теории личности: сравнительный анализ. Перев. И. Авидон, А. Батустин, П. Румянцева. Санкт-Петербург : Речь, 2002. 539 с. 
самоідентифікація, самоповага, «Я-концепція» і всі інтегровані в ній цінності, принципи, потреби та мотиви суб'єкта можна розглядати як механізми стимуляції.

Близькими до теорій самореалізації та ядра особистості є концепції Еріха Фромма та Роло Мея, які мають низку спільних ідей. Так, у теоріях Е. Фромма, які перебувають на перетині двох напрямів (психодинамічного та гуманістичного), ключовим механізмом ядра особистості визначається прагнення індивіда реалізувати свою людську природу, а основною властивістю цієї людської природи науковець називає здатність суб'єкта пізнавати самого себе й об'єкти, які відрізняються від нього. Якщо індивід володіє таким знанням, він неодмінно починає відокремлювати себе від інших індивідів i предметів навколишнього середовища. Позитивним результатом цього відокремлення є свобода, а негативним - відчуження (ізоляція). Саме свобода та незалежність, які є властивостями людської природи, на думку науковця, можуть привести особистість до вершини творчих досягнень. Мотиваційними механізмами свободи та встановлення незалежних й індивідуальних взаємозв'язків зі світом природи та соціумом $\epsilon$ потреби у встановленні зв'язків, подоланні, пошуку коріння, особистісної ідентичності та системі поглядів. Потреба у встановленні зв'язків бере свій початок із того моменту, коли людина розриває своє тісне єднання із природою i перед нею постає необхідність, використовуючи самосвідомість, інтелект та уяву, налагоджувати комунікацію та взаємини 3 іншими членами суспільства. Потреба в подоланні являє собою мотиваційну основу для проактивного існування. Це прагнення бути продуктивною та діяльнісною особистістю, а не пасивною істотою. Потреба в корінні, за Е. Фроммом, відображає прагнення людини шукати братерські та родинні стосунки 3 іншими чоловіками та жінками. Потреба в ідентичності знаходить свою реалізацію у використанні суб'єктом своїх здібностей, можливостей і талантів. Якщо цього не відбувається, індивід задовольняє потребу шляхом ототожнення себе 3 іншими людьми. Останньою потребою у структурі мотиваційної сфери особистості $є$ ïi прагнення мати власну систему переконань, яку репрезентують стійкі способи сприйняття й осмислення навколишнього середовища.

У світлі теоретичної рефлексії стосовно суті та змісту поняття внутрішньоособистісних стимулів професійної самореалізації варто звернути увагу на такі, визначені Е. Фроммом потреби, як встановлення зв'язків, подолання, ідентичності та системи поглядів. Крізь призму першої процес професійної самореалізації може слугувати способом налагодження соціальної комунікації, взаємин і приналежності до 
конкретної фахової спільноти, що робить індивіда включеним у систему суспільно значущих зв'язків і дає можливість вираження свободи за допомогою самостійного вибору професії та виконання трудової діяльності. Потреба в подоланні, що трактується як прагнення особистості бути проактивною, цілком повноцінно може задовольнятись під час професійного розвитку та самореалізації, адже фахова сфера життєдіяльності робить 3 індивіда продуктивного члена соціуму, який не лише вносить вклад у розвиток себе як особистості та своєї локальної громади, а й бере участь у забезпеченні економічної складової частини існування соціуму на загальнодержавному рівні. Потреба в ідентичності як розширення власної самості та реалізації самоповаги відіграє також важливу роль під час вибору фаху й удосконалення себе як професіонала. Зокрема, професійна ідентичність стає частиною загального образу себе й доповнює структуру смисложиттєвих орієнтирів індивіда, за якими його «Я» репрезентує не просто істоту соціальну, а суб'єкта діяльності. Потреба у власній системі поглядів також частково задовольняється за допомогою професійної самореалізації, адже під час фахового становлення й розвитку особистість має можливість організувати набір своїх уявлень, переконань та інтересів у стійку форму світоглядних орієнтирів, норм i правил керівництва своєю діяльністю та життям. Незмінним повинен залишатись той факт, що сама фахова діяльність безпосередньо впливає на життєву філософію суб'єкта, окреслює рамки його самоставлень та ставлення до інших параметрів навколишнього середовища.

Науково-психологічна рефлексія про свободу, а саме незалежність вибору, як один із внутрішньоособистісних стимулів самоактуалізації та самореалізації також представлена в екзистенціальній теорії Роло Мея. Одним із ключових понять його розвідок, через яке автор розкриває мотиваційні механізми діяльності людини, $\epsilon$ інтенціональність. Науковець стверджує, що будь-який вибір індивіда передбачає наявність деякої структури, на основі якої він буде здійснюватися. Такою структурою $є$ інтенціональність, що інтегрує в собі минулий досвід суб'єкта та його уявлення про майбутнє, «структура, необхідна нам, суб'єктам по суті, щоб бачити і розуміти навколишнє середовище, по суті своїй об'єктне. В акті інтенціональності частково долається розрив між суб'єктом і об'єктом». Р. Мей співвідносить це поняття 3 наміром та зазначає: «У намірі закладена дія, а в будь-якій дії наявний намір» ${ }^{8}$. Зазначимо, що поняття інтенціональності в розумінні спрямованості особистості на

${ }^{8}$ Фрейджер Р., Фейдимен Д. Личность: теории, эксперименты, упражнения. Санкт-Петербург : Прайм-Еврознак, 2002. 864 с. 
ті чи ті об'єкти в той чи той проміжок часу фігурує у феноменології Е. Гусерля ${ }^{9}$. Саме ця спрямованість, на думку науковців, детермінує всю поведінку людини, іiі інтереси, цінності, уявлення про світ. Схожим за смисловим наповненням та змістом $є$ поняття самодетермінації в теоріях Е. Десі та Р. Раяна, особистісного потенціалу Д. Леонтьєва, що $€$ здатністю індивіда самостійно, незалежно від інших людей, умов навколишнього середовища й обставин життя обирати вектори саморозвитку. На основі цього припускаємо, що інтенціональність (або самодетермінація) суб'єкта може слугувати ймовірною первинною ланкою внутрішньоособистісних стимулів професійної самореалізації. Якщо у структурі спрямованості індивіда будуть цінності фахового розвитку та професійної діяльності, то процес самоактуалізації неодмінно характеризуватиме здійснення вибору на користь професійного розвитку, кар'єрного зростання та самореалізації у трудовій діяльності.

Усі проаналізовані закордонні концепції ядра особистості як сукупності ймовірних властивостей стимуляції самоактуалізації та самореалізації за своєю суттю та змістом є індивідуалістичними, а тому не дають вичерпного та деталізованого уявлення про природу та структуру мотивації професійної самореалізації. Для уточнення цього варто здійснити теоретичний огляд теорій науковців пострадянського простору, у методологічній основі яких лежать типологічний i системний підходи.

\section{2. Внутрішньоособистісні стимули професійної самореалізації в контексті вітчизняних теорій професійного розвитку}

Д. Леонтьєв, А. Петровський, М. Гінзбург, Л. Коган і О. Асмолов уважають, що у процесі професійної самореалізації мотиваційну функцію виконує уявлення особистості про себе, а саме суб'єктивна перспектива ії професійної самореалізації ${ }^{10}$.

На визначальній ролі різних образів «Я-концепції» особистості та їх співвідношення у процесі професійного розвитку та становлення наголошувала Л. Мітіна. Дослідниця стверджує, що професійний розвиток, який триває протягом усього життя індивіда, визначається наявністю суперечностей між «Я-теперішнім», «Я-дзеркальним» та «Я-творчим». Вектором професійної самореалізації є «Я-творче»"11.

\footnotetext{
${ }^{9}$ Гуссерль Э. Картезианские медитации. Пер. с. нем. В. Молчанова. Москва : Академический проект, 2010. 229 с.

10 Митина Л. Личностное и профессиональное развитие человека в новых социально-экономических условиях. Вопросы психологии. 1997. № 4. С. 28-38.

${ }^{11}$ Там само.
} 
В. Журавчик зазначає, що такі властивості мотиваційної сфери особистості, як цінності, настанови й інтереси, безпосередньо впливають на продуктивність процесу професійної самореалізації ${ }^{12}$.

Л. Божович, В. Петровський, І. Кон і М. Гінзбург наголошували на провідній ролі у структурі процесу професійної самореалізації потреби у професійному самовизначенні, яку вони трактували як потребу у формуванні смислової системи, у якій поєднані уявлення про себе та про соціум; ця властивість спрямовує особистість у майбутне та включена в особистісне самовизначення ${ }^{13}$. Власне приналежність до фаху, володіння певними атрибутами професії робить суб'єкт включеним у соціально важливі взаємини, а також дає йому чітке уявлення про те, хто він і який сенс його діяльності. Тому потреба у професійному самовизначенні як один 3 екзистенціально-психологічних феноменів в онтогенезі індивіда може слугувати первинною стимуляційною ланкою процесу професійної самореалізації.

$\mathrm{He}$ менш важливим поняттям у розширенні визначення внутрішньоособистісних стимулів, що $є$ дотичним до понять професійної самореалізації та самоідентифікації, $\epsilon$ фахова самоідентифікація, яка $\epsilon$ результатом трудової діяльності суб'єкта. І. Остапенко визначає цю властивість як один із типів активності особистості, як системне новоутворення, яке закономірно виникає та формується у процесі соціалізації індивіда. Суть професійної ідентифікації науковець пов'язує із ціннісно-смисловою природою взаємодії людини та соціуму ${ }^{14}$.

О. Бодальов, А. Деркач, Л. Орбан стверджують, що фахова самоідентифікація $є$ формою психологічної регуляції діяльності та професійного становлення, а з нею тісно пов'язана структура професійних уявлень особистості, які можуть виступати механізмами формування образів професій. Такі образи інтегрують у собі також уявлення про суб'єкт фахової діяльності, зокрема ціннісно-мотиваційний компонент, професійно важливі властивості та вимоги до представника конкретної професії. Ступінь відповідності цих уявлень реаліям професійно-трудової діяльності детермінує особливості процесу переживання особистістю своєї фахової реалізованості або нереалізованості. Важлива у визначенні внутрішньоособистісних стимулів професійної самореалізації категорія

12 Журавчик В. Формирование готовности студентов образовательных учреждений среднего профессионального образования к профессиональной самореализации. Педагогическое образование и наука. 2008, № 4. С. 68-73.

${ }^{13}$ Божович Л. О мотивации учения. Возрастная и педагогическая психология : хрестоматия. Москва, 1999. С. 88-91.

14 Земба А. Особистісна вимогливість як чинник професійної компетентності (на матеріалі держслужбовців центрів зайнятості) : автореф. дис. ... канд. психол. наук: 19.00.01. Луцьк, 2010. 20 с. 
професійної самооцінки. Так, М. Ларінова зауважує, що ця властивість $є$ частиною загальної самооцінки особистості та виступає важливим психологічним чинником розвитку та становлення фахівця. Науковець виокремлює в ії структурі такі компоненти: самооцінку стратегій фахової діяльності, самооцінку процесу діяльності, самооцінку результату діяльності. О. Козієвська виділяє такі елементи, як: оцінка себе як професіонала, оцінка себе як професіонала у площині міжпрофесійної взаємодії, оцінка себе як професіонала стосовно досягнення вершин фахової діяльності. Змістовим наповненням професійної самооцінки, на думку науковця, є ставлення суб'єкта до професійно значущих параметрів, ділові й особистісні властивості, які визначають якість фахового спілкування, аналітичні вміння й ціннісні орієнтації професійної діяльності ${ }^{15}$.

А. Маркова виокремлює чотири види професійної самооцінки:

- ретроспективну (Я як професіонал учора);

- актуальну (Я як професіонал сьогодні);

- потенційну (Я як професіонал завтра);

- ідеальну (Я як професіонал у майбутньому) ${ }^{16}$.

Усі види професійної самооцінки співвідносимо 3 імовірними компонентами фахової «Я-концепції» та самоідентифікації. Різниця в якісному та змістовному стані оцінок цих параметрів може слугувати внутрішньоособистісним стимулом до самовдосконалення та професійної самореалізації як результату спрямованості суб'єкта в майбутне фахової діяльності та досягнення «Я-ідеального» у професії.

Для ефективного здійснення фахового самовизначення, професійної самооцінки та професійної самореалізації як результату професійного розвитку необхідний високий рівень функціонування професійної рефлексії, що також може містити в собі смислові та змістовні аспекти стимуляції. Феномен професійної рефлексії виникає на основі загальної рефлексії особистості та виступає комплексом уявлень про себе як фахівця та професіонала, самооцінку та самоаналіз продуктів особистої трудової діяльності ${ }^{17}$.

В. Демський виокремлює такі значення рефлексії у фаховій діяльності, як:

- тенденція розвитку всіх сучасних соціальних систем, пов'язана із загальним позитивом, гуманістичною основою;

- внутрішній контроль професійної діяльності: самоаналіз, свідомий вибір фаху та способів діяльності в ньому;

\footnotetext{
15 Там само.

${ }^{16}$ Там само.

17 Там само.
} 
- будь-яка рефлексія у своїй основі містить сумніви в собі, у своїх переконаннях та можливостях, що може призводити до двох наслідків: 1) песимістичного, що зумовлює пасивність та відсутність віри в успіх; 2) оптимістичного, що стимулює до активності, подолання труднощів, реалізації саморозвитку та самовдосконалення;

- рефлексія не лише $\epsilon$ констатувальним елементом у процесі самоаналізу та самооцінки, а й виконує роль спонукання до саморозвитку, збагачення та примноження фахових знань, умінь та навичок ${ }^{18}$.

Припускаємо, що професійна рефлексія є тим чинником, який стимулює початок самоаналізу щодо професійного самовизначення у старшому підлітковому та юнацькому віці, а також продовжує впливати на становлення фахової ідентифікації та виникнення потреби у професійній самореалізації упродовж здобуття фахової освіти, засвоєння норм, правил і ролей у безпосередній професійній діяльності, тісно взаємодіє із професійною самооцінкою та допомагає суб'єкту кристалізувати фахову «Я-концепцію», удосконалювати свої компетенції у процесі професійного розвитку.

Результатом рефлексії може слугувати виникнення образу професії у свідомості індивіда під час його професійного навчання. До образу у феноменологічному дискурсі можемо віднести вироблені особистістю еталони, ідеали, стандарти та рефлексії, які слугують засобами саморегуляції. Формування комплексного образу допомагає усвідомленню й осмисленню ціннісно-смислової суті трудової діяльності. Феноменальність виявляється в образі професії, що репрезентований у свідомості фахівця, у його ставленні до ціннісносмислових та мотиваційно-вольових аспектів професійної діяльності. Екзистенційний зміст пошуків себе у професії, його співвіднесеність із суб'єктивним досвідом переживань індивіда здійснюється через виконання професійної ролі (М. Хайдегер і Е. Гусерль). Свідома професійна діяльність можлива за умови засвоєння образу професії як цілі, у прагненні до ії реалізації, у позитивному ставленні до виконання фахової ролі, у переживаннях досвіду втілення своїх умінь, знань i навичок у професійній практиці та процесі професійної самореалізації $^{19}$. Якщо образ майбутньої фахової діяльності достатньо позитивний і привабливий для суб'єкта, то він може слугувати для нього ціллю фахового навчання та професійної діяльності, є еталоном,

\footnotetext{
18 Там само.

19 Кораблина Е. Концепция психологической подготовки к профессиональной деятельности. Психологические проблемы самореализаиии личности / под ред. Л. Коростылёвой. Санкт-Петербург : Изд-во С.-Петерб. ун-та, 2007. Вып. 11. 272 с.
} 
до якого варто прагнути, виконує роль внутрішньоособистісної стимуляції в самооцінці, самовдосконаленні та професійній самореалізації.

\section{ВИСНОВКИ}

Отже, аналіз закордонних і вітчизняних теорій самоактуалізації, самореалізації та ядра особистості дозволяє визначити два рівні внутрішньоособистісних стимулів професійної самореалізації. Так, до першого рівня доцільно віднести такі, як загальну потребу в самоактуалізації та самореалізації, професійному самовизначенні та виконанні професійної діяльності як способу сублімації почуття вини й інших несвідомих імпульсів індивіда, отримання задоволення від належності до соціуму через загальноприйняту творчу та фахову діяльність і здійснення суспільно значущої роботи, реалізацію й розширення самості («Я-концепції»), підтвердження свого існування в системі суспільних i економічно-трудових відносин через формування професійної ідентифікації. Другий рівень утворюватимуть індивідуальні мотиваційно-смислові аспекти професійної діяльності це й отримання позитивного суспільного схвалення, позитивної уваги до себе, через що підвищення фахової й особистісної самооцінки; мотиви досягнення успіху та компенсації чи то психоемоційного, чи то матеріального, чи будь-якого іншого дефіциту. Додатковою стимуляцією професійної самореалізації є професійна самооцінка та рефлексія, формування образу професії під час здобуття фахової освіти, а також інші складові частини особистісної мотиваційно-вольової сфери (інтереси, настанови, стандарти, цінності, цілі тощо).

Також шляхом детального та глибинного огляду теорій ядра особистості в дискурсі концепцій психодинамічного, гуманістичного, екзистенційного та феноменологічного підходів визначено, що джерелом будь-якої системи внутрішньоособистісних стимулів $\epsilon$ глибинні рушійні сили розвитку психічного та психологічного індивіда, зокрема, до цих властивостей можемо віднести:

- самодетермінацію (інтенціональність) суб'єкта;

- наявність інтрапсихічного або психологічного конфлікту між структурами психічного апарату та між інстинктивними імпульсами й мотивами особистості, що потребує сублімації в соціально значущій діяльності;

- потреба актуалізації вродженого потенціалу, що інтегрує в собі прагнення самоактуалізації та самореалізації шляхом розширення самості, здійснення власної «Я-концепції»; 
- спрямованість на соціально активну взаємодію, пошук позитивного суспільного схвалення власних дій та позитивної уваги до себе;

- підтвердження свого «Я» за допомогою «легалізованої» суспільством та культурою творчої й наукової діяльності.

За допомогою виокремлених глибинних властивостей стимуляції поведінки індивіда пояснені причини виникнення в особистості потреби професійної самореалізації та визначено комплекси внутрішньоособистісних стимулів на кожному етапі професійного розвитку, а саме фахового самовизначення, здобуття професійної освіти, реалізації трудової діяльності. Зокрема, для здійснення вибору професії та подальшого успішного навчання необхідна наявність потреби в самореалізації саме у професійній діяльності, володіння образом професії, здійснення постійної самооцінки компонентів професійної «Я-концепції», прагнення до самовдосконалення та досягнення успіху.

\section{АНОТАЦІЯ}

Стаття містить усебічний аналіз змісту поняття внутрішньоособистісних стимулів професійної самореалізації крізь призму психоаналітичної та гуманістичної наукової парадигми Заходу та системного вітчизняного підходу в дослідженні професійного розвитку особистості. Ця розвідка $\epsilon$ частиною теоретичного конструювання структури виокремленої психологічної властивості, що, на думку авторів, $є$ основоположною в ресурсному забезпеченні фахового становлення молоді. Зокрема, у статті висвітлено два гіпотетичні рівні функціонування внутрішньоособистісних стимулів професійної самореалізації. Так, у процесі аналізу психоаналітичного, гуманістичного й екзистенційного дискурсу як глибинне особистісне ядро, що стає спонуканням до визначення професійної самореалізації як важливої життєвої цінності, виокремлено такі аспекти, як: природне вроджене прагнення до актуалізації фізичного та творчого потенціалу, як на рівні організму, так i на рівні особистості; сублімація деструктивних інстинктивних потягів, що можуть набувати форм легалізованого задоволення лише в системі соціокультурних стосунків, серед яких основне місце посідає фахова трудова діяльність; найбільш ефективне втілення та реалізація «Я-концепції» можлива через виконання професійно зорієнтованих ролей, а розширення самості відбувається через засвоєння цінностей, норм і досвіду фахової спільноти. Крім усього зазначеного, важливою мотиваційною функцією позначене прагнення суб'єкта отримати позитивне схвалення соціуму, що прямо залежить від його успіхів у професійній царині. 
У результаті аналізу наукових праць вітчизняних психологів, присвячених проблематиці, порушеній у статті, серед важливих структурних елементів внутрішньоособистісних стимулів професійної самореалізації другого рівня виокремлено такі, як індивідуальні мотиваційно-смислові аспекти професійної діяльності, професійна самооцінка та рефлексія, формування образу професії під час здобуття фахової освіти. Також автори статті здійснили спробу феноменологічного осмислення предмета дослідження, що втілилось в акцентуванні уваги на важливій ролі інтенціональності у виборі фаху та подальшому професійному розвитку особистості, зокрема його найвищого результату - професійної самореалізації.

\section{ЛІТЕРАТУРА}

1. Божович Л. О мотивации учения. Возрастная и педагогическая психология : хрестоматия. Москва, 1999. С. 88-91.

2. Гуссерль Э. Картезианские медитации. Пер. с. нем. В. Молчанова. Москва : Академический проект, 2010. 229 с.

3. Журавчик В. Формирование готовности студентов образовательных учреждений среднего профессионального образования к профессиональной самореализации. Педагогическое образование и наука. 2008. № 4. С. 68-73.

4. Земба А. Особистісна вимогливість як чинник професійної компетентності (на матеріалі держслужбовців центрів зайнятості) : автореф. дис. ... канд. психол. наук: 19.00.01. Луцьк, 2010. 20 с.

5. Кон И. В поисках себя: личность и самосознание. Москва : Политиздат, 1984.335 с.

6. Кораблина Е. Концепция психологической подготовки к профессиональной деятельности. Психологические проблемы самореализации личности / под ред. Л. Коростылёвой. СанктПетербург: Изд-во Санкт.-Петербургского. ун-та, 2007. Вып. 11. 272 с.

7. Леонтьев Д. Жизненный мир человека и проблема потребностей. Психологический журнал. 1992. № 2. С. 107-116.

8. Мадди С. Теории личности: сравнительный анализ. Перев. И. Авидон, А. Батустин, П. Румянцева. Санкт-Петербург : Речь, 2002. 539 c.

9. Митина Л. Личностное и профессиональное развитие человека в новых социально-экономических условиях. Вопросы психологии. 1997. № 4. C. 28-38.

10. Петровский А. Развитие личности и проблема ведущей деятельности. Вопросы психологии. 1987. № 1. С. 15-26.

11. Степанов О. Психологічна енциклопедія. Київ : Академвидав, 2006. 424 c. 
12. Татенко В. Субъект психологической самореализации: поиск новой парадигмы. Психологический журнал. 1995. № 3. С. 23-34.

13. Фрейд 3. Недовольство культурой. Санкт-Петербург : Фолио, 2013. $222 \mathrm{c}$.

14. Фрейджер Р., Фейдимен Д. Личность: теории, эксперименты, упражнения. Санкт-Петербург : Прайм-Еврознак, 2002. 864 с.

15. Rogers, C. The necessary and sufficient conditions of therapeutic personality change. Psychotherapy: Theory, Research, Practice, Training. 2007. № 44 (3). 256 p.

16. Ryan R., Deci E. On Happiness and Human Potentials: A review of research on hedonic and eudaimonic well-being. Annual Review of Psychology / S. Fiske (Ed.). Palo Alto, CA : Annual Reviews, Inc., 2001. Vol. 52. 141-166 p.

\section{Information about the authors:}

Mazai L. Y.,

Master of Psychology,

Teaching Assistant at the Departure of Psychology and Social Work of the Educational and Scientific Institute of Pedagogy,

Psychology and Postgraduate Training of the Vinnytsia Mykhailo Kotsiubynskyi State Pedagogical University 32, Ostrozkoho str., Vinnytsia, 21000, Ukraine

Pavlushenko O. A., Candidate of Philological Sciences, Assistant Professor at the Departure of Ukrainian Language of the Departure of Philology and Journalism named after Mykhailo Stelmakh Vinnytsia Mykhailo Kotsiubynskyi State Pedagogical University 32, Ostrozkoho str., Vinnytsia, 21000, Ukraine 